\title{
Internal supply-chain competition in remanufacturing: operations strategies, performance and environmental effects
}

\author{
George Papachristos* and Emmanuel D. Adamides ${ }^{\dagger}$ \\ Section of Management and Organisational Studies \\ Department of Mechanical Engineering and Aeronautics \\ University of Patras, Rion 26500, Greece
}

\begin{abstract}
This paper investigates the competitive and environmental effects of different operations strategies of Original Equipment Manufacturers (OEMs) and semi-independent remanufacturers, which simultaneously cooperate and compete in different stages of a closed-loop supply chain. In particular, a co-opetitive situation, in which remanufacturing is undertaken only by retailers while the OEMs' role is restricted to recycling is considered. After adopting a resource-based perspective of competition, investigations are accomplished using system dynamics simulation modelling. The results of simulations indicate that, in the long run, OEMs, regardless of the operation strategy they adopt, are unable to (re)capture the market gained by the remanufacturers. However, some of these strategies contribute to the improvement of the environmental performance of the entire supply chain.
\end{abstract}

Keywords: closed-loop supply chain, remanufacturing, operations strategy, resource-based view, system dynamics

\footnotetext{
* Now at Policy Analysis Section, Faculty of Technology, Policy and Management, Delft University of Technology, Netherlands. E-mail: G.Papachristos@ tudelft.nl

${ }^{\dagger}$ Corresponding author. E-mail: adamides@ @mech.upatras.gr
} 


\section{Introduction}

The environmentally benign supply chain, as a distinct stream in supply chain research has increasingly attracted the interest of many researchers over the last years (Seuring and Müller, 2008; Gavronski et al., 2011; Sarkis et al., 2011; Setaputra and Mukhopadhyay, 2010). In particular, closed-loop supply chains and reverse logistics have been extensively researched areas. Both qualitative and quantitative methodologies have been used in addressing issues of network design and operations, assuming OEM's ownership of the reverse chain, or cooperating partners (e.g. Atasu et al., 2009; Blumberg, 2002; Carter and Ellram, 1998; Dowlatshahi, 2000; El korchi and Millet, 2011; Fleischmann et al., 2000; Guide et al., 2000; Heese et al., 2005; Jaber and El Saadany, 2009; Kumar and Putnam, 2008; Őstlin et al., 2008; Robotis et al., 2004; Seitz, 2007; Srivastava, 2007; Thierry et al., 1995). In quantitative studies, a variety of deterministic and stochastic models have been employed (Akçalı and Çetinkaya, 2011; Das and Chowdhury 2012; Fleischmann et al., 1997; Fleischmann et al., 2001; Gharbi et al., 2008; Gu and Ji, 2008; Jayaraman et al., 2003; Mondal and Mukherjee, 2006; Qiang et al., 2013; Savaskan et al., 2004; Shulman et al., 2011), including system dynamics models which, however, have been built mainly for investigating purely operational issues, i.e. competition has not been explicitly taken into account (e.g. Georgiadis and Athanasiou, 2013; Spengler and Schroter, 2003; Vlachos et al., 2007).

Nevertheless, very little attention has been paid to competition in remanufacturing supply chains, i.e. when remanufacturers compete with OEMs (Atasu et al., 2009; Mitra and Webster, 2008; Östlin et al., 2008; Toffel, 2004). Research in this area has focused on determining, and/or justifying, OEM incentives for reclaiming materials and equipment, or with OEM strategies for pre-empting the entry of third parties in the secondary (remanufactured items) market (Debo et al., 2005; Kumar and Putnam, 2008; Seitz, 2007). At the operations level, Majumder and Groenevelt (2001), using a two-period game-theoretic model, investigated market-based competition between an OEM and a local remanufacturer. Their model assumes perfect substitution between OEM's new and remanufactured products, both being distinguishable from the local remanufacturer's products. It further assumed that used items are externally allocated to the competitors, pricing is static, and learning effects are not taken into account. They concluded that in order to have profitable operations, both competitors (OEM and remanufacturer) should cooperate to keep the return incentives for customers low. A similar approach was adopted by Kleber et al. (2011) for deriving an analytical framework for 
investigating the inherent characteristics of spare parts management for durables, and the effects of part recovery along a closed-loop supply chain.

Building on Majumder and Groenevelt's model, Ferguson and Toktay (2006) analysed the OEM's strategic dilemma to, either engage in remanufacturing competition or launch a collection programme and pre-empt local remanufacturers. In their model, it is assumed that when the OEM remanufactures, local remanufacturers are excluded, and that the OEM's new and remanufactured products are distinguishable to those of the local remanufacturers. They concluded that both strategies are viable depending on the specifics of cost structures. Extending the above research, Debo et al. (2006) considered competition among OEMs and showed that remanufacturing is more profitable for slowly diffusing products, while high sales of new and remanufactured products make the availability of flexible capacity more valuable. In the same line, Richey et al. (2004) adopted a resource based view of competition and used an empirical research methodology to investigate the importance of timing and resource commitment for introducing reverse logistics programmes, on the competitiveness of an OEM. They concluded that both have a positive effect. Finally, Atasu et al. (2008), using a model of a two-segment market (normal and "green") showed that remanufacturing can become an effective marketing strategy for an OEM, although there are cases where remanufactured products cannibalised new product sales (especially when the OEM acted also as remanufacturer). In such cases, especially for consumer products, an important role is played by the relative perceptions of the customers, concerning the value of brand and remanufactured products, which depends on whether the OEM remanufactures or not (Agrawal et al., 2012).

The above brief literature survey reveals three important gaps in the research that concerns competition in closed-loop supply chains with remanufacturing. First, there has been no explicit consideration of the case of a non-remanufacturing OEM competing with its remanufacturing retailers. This is an increasingly important situation of co-opetition (i.e. OEMs and retailers cooperate to increase the value offered in brand new products, while at the same time compete for capturing the value embedded in used products, through remanufacturing and recycling (Nalebuff and Brundenburger, 1996)) in markets of functionality-seeking customers, especially in periods of shrinking economies. Second, there is a gap concerning the study of the dynamics of internal competition in remanufacturing closed-loop supply chains with the use of analytic or quasi-analytic methods under the resource-based perspective. At the level of operations, this competition concerns the accumulation of resources, and, inevitably, the focus of research should 
be on the study of operations strategies for the management of the resource flows and the feedback processes in which they are involved. However, in the research reported so far, with a few exceptions (Gavronski et al., 2012), operations have been overlooked as a milieu of strategic interventions, mainly because competition has been assumed to be market-based in static markets and market segments. Hence, competitive strategy constructs, such as price setting and binary market decisions (enter-exit), have been more popular in models in comparison to modelling explicitly the dynamics of operations-related strategic decisions and their interactions. Third, and most important, in previous research no explicit consideration has been given to the effect of competition on the natural environment. This effect has been widely assumed to be the principal motivator for remanufacturing, but the question whether the positive environmental effect of remanufacturing strategies is in all cases conducive with achieving business performance has not been clearly answered yet. The research presented in this paper aims at filling these gaps.

Towards this end, a system dynamics model of internal supply chain resource-based competition was developed and used to explore trade-offs and synergies in business and environmental strategic objectives in the above context of co-opetition. System dynamics models have been considered as the most appropriate means to capture the dynamics of resource stock accumulations at various levels of analysis (Mollona, 2002; Morecroft, 2007; Warren, 2008). The paper employs system dynamics modelling of resources at the level of operations strategy. It primarily concerns sectors characterised by functionality-seeking customers, such as the industrial equipment sector to which explicit reference is made, but the results obtained are of value to other capital goods sectors (e.g. shop-floor transportation equipment), which may have greater economic and environmental impact.

Following, in Section 2, a brief presentation of the situation that motivated our research is made and its generalised version is analysed under a resource-based operations strategy theory perspective. In Section 3, the assumptions for modelling and the system dynamics simulation model used to carry out the investigations are presented, while in Section 4 the results of the explorative study are depicted and commented. An assessment of their sensitivity to modelling assumptions is also included in this section. A discussion of the overall research endeavour is presented in Section 5, before the conclusions are drawn. 


\section{Motivation, theory, and development of research questions}

\subsection{Motivation - A case of remanufacturing with internal supply-chain competition}

The research reported in this paper was motivated by a case involving a large industrial equipment OEM and a remanufacturer. Stainless Steel Tanks (SST) S.A. (name disguised for confidentiality) is based in Greece and it is one of the largest manufacturers of stainless steel industrial equipment in the South East of Europe. The company manufactures stainless steel tank-like equipment (fermenters, stabilisers, vinificators, oil and milk vats, etc.) used in the food and alcoholic beverages industries. These products are equipped with motors and electromechanical components, such as valves, shakers, sensors, etc., as well as heating and cooling jackets, which can be easily replaced. SST's downstream supply network includes a distribution centre/warehouse, four regional distributors, retailers all over the country, and agents/resellers in five other neighbouring countries. With the exception of custom products and turn-key projects, all installations and maintenance are undertaken by the retailers.

Fifteen years ago, SST started a collection and recycling programme for bulky tanks. Collecting small tanks, assessing their condition, transporting them to its manufacturing facilities and eventually remanufacturing has always been considered a very costly enterprise for SST, especially for foreign markets. Hence, the programme was outsourced to a third party steel producer that was a supplier of SST. A couple of years later, one of the SST's distributors abroad started remanufacturing small tanks (washing, treating oxidized areas, galvanizing, and replacing electro-mechanical parts), after collecting them from the retailers when customers renewed or upgraded their equipment. However, as more customers were looking for more economic solutions, the distributor-turned-remanufacturer built capacity for remanufacturing larger equipment. Eventually, a parallel closed-loop supply chain of reconditioned/ remanufactured equipment was set in operation, in addition to the (forward) supply chain of SST's brand new products. Although the collection activity had been initiated by the OEM for economic and environmental reasons, in the end, the reverse chain was mainly controlled by two distributors and a small number of large retailers situated near industrial districts. The attractiveness of the SST brand name was overshadowed by the close, sometimes personal, relationships between customers and retailers that had monopolistic positions, as far as remanufacturing activities in specific geographic areas were concerned. There were no legal barriers for remanufacturing, and 
both the OEM and the remanufacturers, as it happens in many cases, had no clear incentives to cooperate (Atasu at al., 2009; Cheng and Chang, 2012). In addition, the close customer-retailer relationships have stabilised market segment boundaries among competing OEMs, i.e. customers rarely switched from one brand to another, neither from one retailer to another. So, effectively, in each individual geographic area, competition has been only between SST and the local remanufacturer, who is also a retailer or reseller, of SST's products. SST has tried various strategies to counter the remanufacturing operations of resellers and retailers without much success so far.

\subsection{Strategic analysis of the motivating case - a resource-based theory perspective}

The motivating case of SST can be generalised in sectors with functionality-seeking customers where competition takes place between any OEM and the retailers that remanufacture its products. In such a context, the strategies of remanufacturers are focused towards achieving market performance in terms of cost/price, on-time delivery, and proof of good functionality, comparable or superior to, that of the OEM. The achievement of these performance objectives is highly dependent on the resource stocks and activities of the OEMs and remanufacturers. The remanufacturer's operations-strategy-related resources are: remanufacturing capacity, trust (customer trust is a matter of geographic proximity and frequent face-to-face interaction), and number of customers. The last two resources have a mutually reinforcing relationship, so that the measurement of customers can be a sufficient indicator of the state of both resources.

In order to protect their market position from remanufacturers, OEMs are obliged to manage the levels of their resource stock which contribute to achieving the same operations strategy performance objectives (Dierickx and Cool, 1989; Kunc and Morecroft, 2009). Speed and flexibility are not important operations strategy performance objectives for the case of internal supply chain competition in sectors of capital goods, while quality can be linked to the production know-how resource stock which increases with cumulative production. Since, in contrast to consumer goods (Agrawal et al., 2012), quality as a value-enhancing attribute is not a direct order winning criterion (Hill, 2000; Kumar et al., 2011; Pettersson and Segerstedt, 2012), the net effect of the improvement of the operations-related quality (error-free processing) is reflected in the reduced product unit cost which depends on the production know-how resource stock. In addition to production know-how, the OEMs resources include manufacturing capacity, 
and product technology. The levels of the last two resource stocks determine the OEMs' products brand name, which may be assumed to be equivalent to, and measured by, the level of the resource stock customers (sales), i.e. how much the product and process technology of the OEM are valued in the market. Recycling technology and recycling capacity are also important resources of OEMs (Abdessalem, et al., 1012). Customers (sales) is also a resource that contributes to their competitiveness. However, it depends on the product unit cost/price and availability and hence it develops gradually in accordance with the development of the other two operations-related resources (capacity and production know-how).

The management of the OEMs' and remanufacturers' resource stocks requires the management of the associated resource accumulation processes. Viewing firms as networks of resource stocks and flows, Dierickx and Cool (1989) indicated that resource stock levels cannot be adjusted instantaneously. It is only through managing patterns of flows that stocks can reach desired levels. Therefore, competition on resource stock levels concerns the management of these flows (activities). Preventing a competitor from achieving the same or higher, resource stock levels, is feasible by either accelerating the flow of one's own resources, or slowing down (if possible) those of the competitor/imitator, or both. In this context, the management of the above mentioned tangible and intangible resource stocks associated with the operations performance objectives of both competitors, can be accomplished by regulating their associated resource flows through decision making in four broad operations strategy decision areas (Slack and Lewis, 2008; Lewis et al., 2013): i) capacity management decisions for regulating the capacity stock levels for the production of OEM's new products and for recycling by the OEMs, as well as for remanufacturing by the retailers, ii) supply chain and logistics management decisions which concern the flow of products (new and used) in the supply chain, and the way capacity is being used (Sheriff, et al., 2012; Xanthopoulos and Iakovou, 2010), iii) organisational learning and operational improvement decisions which concern the rate of improvement of manufacturing, remanufacturing, and recycling operations and consequently, the rate of accumulation of the production know-how resource stock, and iv) decisions on the rate of acquisition and use of product and process technology (Hazen, 2011). However, since both competitors have equal access to product and process technology factor markets, and products are not technologically complex, technology cannot be considered as a distinctive strategic decision area which contributes significantly to any operations strategic objective. 
In the Dierickx and Cool (1989) perspective of competition, there are certain characteristics of accumulation processes that are important for the strategic behaviour (decision making) of competitors. The characteristic of time compression diseconomies (difficulty to achieve the same level of stock in a much shorter time) suggests the adoption of an operations strategy of preemptive resource development, to outcompete even faster resource stock accumulation processes by competitors. The same pre-emptive strategy seems appropriate when a competitor aims at taking advantage of asset mass efficiencies (high stock levels reinforce the related rates of increase). Finally, the characteristic of resource stocks interconnectedness (resource stocks interdependence determines the dynamics of accumulation) implies strategies for regulating resource flows, at different points in the network of stocks and flows, which have indirect impact on the associated stocks.

In theory, production improvement programmes that rely on learning-by-doing tend to increase the efficiency of production (and reduce costs) with cumulative production, and competitors can take advantage of the time compression diseconomies associated with them. However, in the specific case of co-opetition, the OEMs logically cannot rely on time compression diseconomies based on the fact that they have been manufacturers for a long time before retailers start remanufacturing. Since remanufacturing is a relatively simple process, the retailers can easily reach the same effective level of production efficiency (Zhou et al., 2013). Hence, remanufacturers will be in a superior position, in terms of cost and dependability forcing OEMs to improve their efficiency. Anticipating this situation, the OEMs can either: (i) manage strategically their capacity and production know-how by pre-emptively developing recycling capacity and/or accelerating their learning (improvement of production), so that more used products are attracted, and recycling contributes more to the cost reduction of brand products (asset mass efficiency), or/and (ii) take advantage of the dependence of retailers on them, and intentionally adopt rationing (partial order fulfilment) (Tan et al., 2009), at regular or irregular time intervals, in order to regulate the flow of new products to the market in a way that creates an undersupply or delayed oversupply of used products to the retailer's remanufacturing operations. In the case of undersupply it is anticipated that retailer's built remanufacturing capacity will be underutilised, resulting in higher costs and low competitiveness. In the case of oversupply they will face remanufacturing undercapacity, order backlogs and they will be forced to ship surplus stocks to the OEMs for recycling. 
The above discussion leads to the following four questions which are investigated, in a systematic way, below using a set of simulation experiments:

1. Does pre-emptive recycling capacity development by the OEMs make their operations more competitive?

2. Does order rationing (partial fulfilment of retailer orders, intentional or due to inherent production limitations and delays) by the OEMs result in the retailers experiencing remanufacturing overcapacity or/and undercapacity?

3. Do more intense production improvement efforts by the OEMs increase their competitiveness in comparison to that of the retailers?

4. Do the OEMs' competitive moves guarantee consistency with the objective of increased environmental performance?

\section{System dynamics modelling}

\subsection{Assumptions for modelling}

To investigate the above research questions, a system dynamics simulation reference model has been developed involving two co-opetitors, the OEM and a retailer-remanufacturer. The assumptions and the operational characteristics (scaling, and initial settings of variables) of this model were based on the industrial equipment sector case mentioned above with appropriate modifications and abstractions to allow for generality. As a result, in the model, the brand products market size and the use period have been chosen to correspond to the real average values for the case of medium-to-large tanks solely (i.e. small values for better model sensitivity). The model represents, a single product, two-segment (primary and secondary) market, served by a retailer company that sells the brand name product of the OEM, as well as its own remanufactured product. Demand is assumed to be insensitive to marketing initiatives and government regulation. In fact, each segment corresponds to the products of each competitor.

The retailer is assumed to serve a geographically-bounded market with no competition from other retailers. Therefore, there is no competition among OEMs. The forward supply chain operates according to a pull, lot-for-lot order fulfilment policy. The retailer is the sole collector of after-use products. When the required processing capacity is available, used products are remanufactured by the retailer, otherwise they are forwarded to the OEM for recycling and the 
materials are used in the production of new products. The retailer does not recycle and does not discriminate items for remanufacturing from items for recycling. Products go through only one remanufacturing cycle. Initially, the secondary market is only a small fraction of the entire market that grows annually at a fixed rate.

The retailer has no preference in satisfying the demand for new or remanufactured products ("perfect" co-opetitor). It is assumed that it just follows the demand for both. On the basis of the demand, it initiates the development of remanufacturing capacity with a certain level of expectation and commitment. The retailer increases its remanufacturing capacity with a six month delay, by committing more resources and effort, and becomes operationally more efficient in collecting after-use products and remanufacturing them. The OEM follows a similar recycling capacity management policy, though its development is assumed to be faster than that of the remanufacturer. The remanufacturer enters the market with products that have a lower price compared to the new ones. Nevertheless, pricing is dynamic; prices depend on unit production cost, which is influenced by the improvement initiatives and learning effects in the manufacturing, remanufacturing and recycling processes. In addition, the OEM's production cost is affected by the amount of recycled used products (recycled materials are used as substitutes for new ones).

\subsection{Description of the model}

The core structure of the system dynamics (SD) model (materials flow infrastructure and decision variables) developed in Powersim Studio ${ }^{\circledR}$ simulation environment is depicted in Figure 1. In the symbolic language of system dynamics, resources are modelled as stocks whereas resource accumulation and depletion activities and processes are represented as flows (Morecroft, 2007; Warren, 2008). Usually, the rates of activity (or process) execution are regulated by auxiliary variables (a class of intermediate variables used in SD models to calculate values that can be accessed by different flow variables), as well as by the levels of resource stocks. The model was calibrated using absolute and relative values from the SST case. 


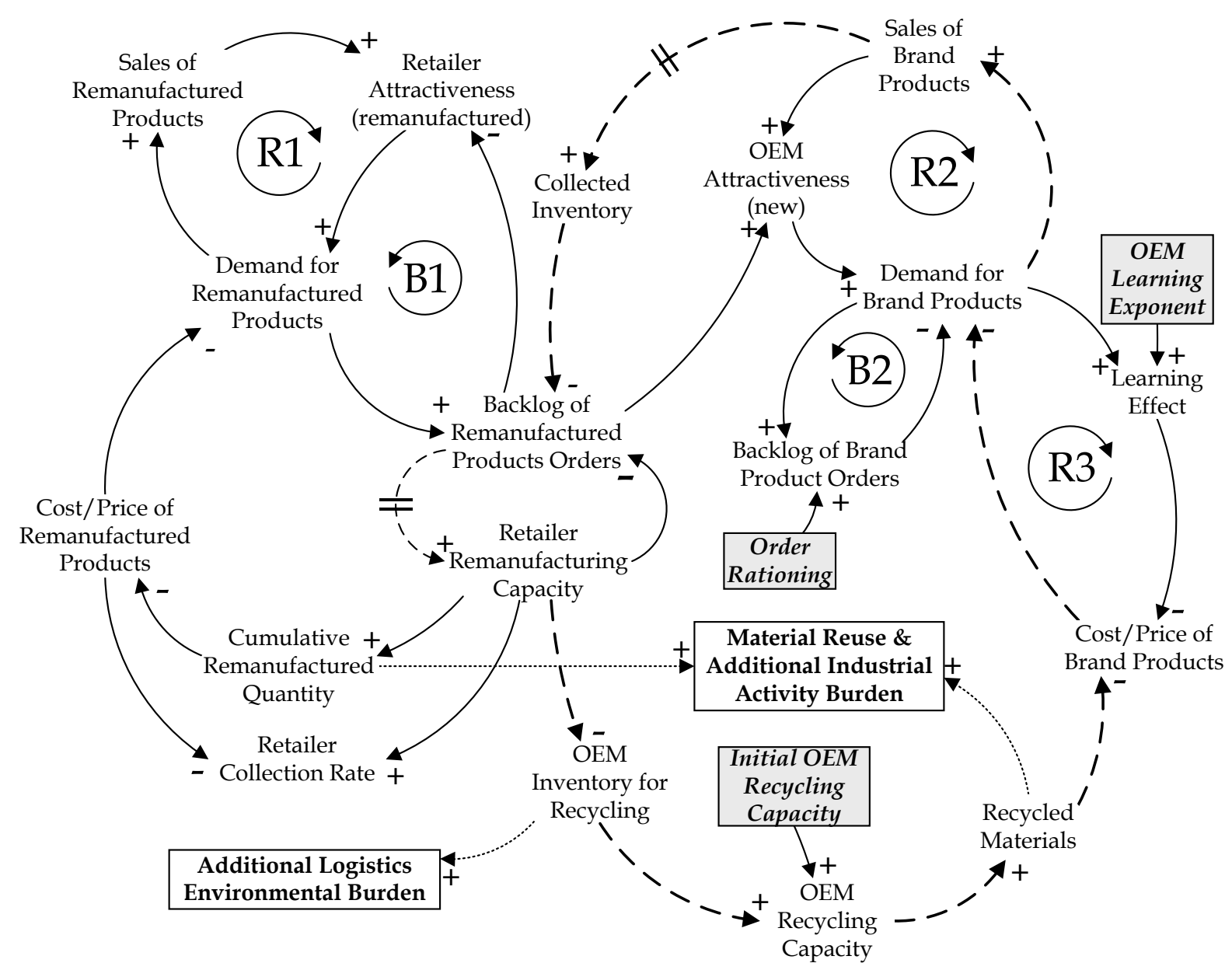

Figure 1 A qualitative system dynamics representation of competition in the remanufacturing supply chain.

In the model, the flow of customers between the two market segments is regulated by the flow variable Market_Shift which depends on the relative attractiveness of the product offerings of the two competitors (Retailer_Attractiveness and OEM_Attractiveness, respectively). More specifically,

$$
\begin{aligned}
& \text { OEM Attractiveness }=\frac{\text { Retailer Order Backlog }}{\text { Total Demand }} \times \frac{\text { Retailer Unit Price }}{\text { Retailer Unit Price }} \\
& \text { Retailer Attractiveness }=\frac{\text { Brand Order Backlog }}{\text { Total Demand }} \times \frac{\text { OEM Unit Price }}{\text { Retailer Unit Price }}
\end{aligned}
$$

Market Shift $=\frac{\max (\text { Retailer Attractiveness- OEM Attractiveness, OEM Attractiveness- Retailer Attractiveness) }}{\text { OEM Attractiveness }+ \text { Retailer Attractiveness }}$

In the above relationships, Total Demand is the sum of Demand for Remanufactured Products and Demand for Brand Products. Since there is a bidirectional flow between the two types of demand (customers), increase in one triggers a proportional decrease in the other. Relationship 
(3) above calculates the magnitude of the market shift (measured in products sold per year, one for each customer), while its direction is set by the relative attractiveness of the OEM's and retailer's products (shift is towards the largest). In the model, the retailer is assumed to collect all used products and store them in Collected_Inventory before remanufacturing and in Retailer_Remanufactured_Inventory afterwards. If the retailer lacks adequate remanufacturing capacity, surplus collected items are forwarded to the OEM for recycling (first to OEM_Inventory_for_Recycling then to OEM_Recycling).

The retailer adds remanufacturing capacity according to the variable Retailer_Undercapacity_Ratio defined as:

$$
\text { Retailer Undercapacity Ratio }=\text { Retailer Indicated Capacity-Prospective Retailer Capacity }
$$

The Retailer_Indicated_Capacity is based on brand product orders. Prospective_Retailer_ Capacity is the capacity planned by the retailer on the basis of the collected products. It becomes effective after a certain period of time. Values for Retailer_Undercapacity_Ratio are calculated quarterly and their annual average value is is the target value of capacity to be built by the retailer. The decision for adding (or not adding) capacity is based on this target value, but capacity becomes operational only after some time (a time period is assumed between the decision to build capacity and the time the capacity is available). The Remanufacturing flow variable represents the rate of remanufacturing and is subjected to capacity constraints.

In the model the OEM adds capacity according to the rate of used products forwarded by the retailer (Retailer_Returns), its current recycling capacity (OEM_Recycling_Capacity), and the potential contribution that the recycled products can have on the production of brand products. The latter is modelled by the variable Retailer_Returns_OEM_Manufacturing_Ratio,defined as the ratio of the rate of returned quantities of used products to the OEM, over the rate of new products being manufactured. In the model, every recycled item used in manufacturing reduces the amount of required new materials and the corresponding production activity by $30 \%$. The environmental burden of the remanufacturing activity per unit is only $30 \%$ of the corresponding burden of manufacturing a brand new unit. The base value of the percentage learning (experience) coefficient was set to $1.5 \%$ to correspond with the real value for the specific type and size of tanks. Based on the assumptions and choices made with direct reference to the medium-to-large tanks case, already mentioned in Section 3.1, the product use period is three (3) years (in fact, high-end wineries change their tanks every year, whereas mass-producing agrifood 
companies replace their equipment every 6-8 years), and the initial values for the costs of brand and remanufactured products were set to a ratio of 1.3 to 0.8 to also account for the changes in technology and design that occurred during the period of product use. Initially, the secondary market was set to be $10 \%$ of the primary one, which had a magnitude of 1000 units per year. Both markets grow at a rate of $7 \%$ annually.

To calculate the environmental effect of transportation (pollution and consumption of natural resources), in the model, the distances between the market and the retailer, and the market and the OEM, were set to $60 \mathrm{Km}$ and $300 \mathrm{Km}$, respectively. Component suppliers were assumed to be situated at a distance of $60 \mathrm{Km}$ for both co-opetitors. It was further assumed that the average product unit volume was $1000 \mathrm{lt}$, while the average volume of parts required for remanufacturing was $30 \mathrm{lt}$. For both organisations, the logistical environmental impact was calculated on a volume $\mathrm{x}$ distance basis.

\subsection{Model validation}

Conventional statistical approaches are not applicable to behavioural testing of models that are not exact representation of real situations (Larsen and Lomi, 2002; Sterman, 2000) since they are not meant to be exact representations of reality. Nevertheless, the model was tested, in qualitative terms, for the reproduction of the SST's problematic situation, as far as its ability to collect and recycle used tanks was concerned. Hence, the observation of the retailer's increasing remanufacturing activity (variable Retailer Remanufactured Inventory) and the stagnant OEM recycling one (variable OEM Inventory for Remanufacturing) under the assumptions of medium OEM recycling capacity (30 units), no rationing, and normal improvement/learning effort (OEM Learning Exponent $=0.005$ ) was a sufficient indication that the model represented the SST's situation. To test the structural validity of the model, the dimensional consistency test and the extreme conditions tests (Sterman, 2000) were employed. The dimensional consistency test was carried out using Powersim's automatic dimensional consistency test and adjustment. In the extreme value test, the model behaviour was tested for logical consistency under high and zero forcing, as far as the effect of key variables was concerned. For example, when the retailer collection effort was set to zero, no inventory was flowing back through the reverse logistical chain, and no additional capacity was being built by the retailer or OEM. Setting the OEM material procurement to zero, the production flow in the forward supply chain was sustained 
only by the recycling of collected used products, and inventory stocks were considerably lower. In addition, when complete rationing on the part of the OEM was implemented (no shipments to retailer), inventory stocks in the supply chain reduced to zero. Additional tests were implemented to ensure that there were no negative orders, shipments, manufacturing, remanufacturing or recycling rates, and that mass is conserved. Further tests ensured that when the forward supply chain was disconnected from the reverse, and left to operate with constant pricing it reached an equilibrium. In the same way, the complete model with constant remanufacturing and recycling capacity, with no OEM strategies implemented and constant pricing, reaches a dynamic equilibrium, i.e. the demand for brand and remanufactured products, and the production and remanufacturing rates settle into equilibrium. In addition, behavioural sensitivity and policy sensitivity tests were conducted, the results of which are given in Section 4.4.

\section{The competitive and environmental effects of OEM's operations strategies}

In order to investigate the research issues stated at the end of Section 2.2, a number of simulations were conducted. Simulation period was 6 years with a time step of 0.5 weeks. This was dictated by the smallest time period/unit in the model, which was the shipment delay (1 week). Simulation runs conducted with smaller time steps, up to 0.125 weeks, did not change the quantitative and qualitative aspects of the results. Euler integration was chosen because the dynamics of the simulation were relatively slow compared to the time step (OEM production, remanufacturing and many other flows concern annual values). In line with the analysis of Section 3, the model variables that were used for implementing the OEM's strategies (the decision variables) were: Initial_OEM_Recycling_Capacity (level of capacity pre-emption) with values ranging from 1 to 120 product units per year and step 20, Order Rationing with values ranging from $0 \%$ to $60 \%$ and step 10\%, and OEM_Learning_Exponent (the exponent's value in the negative exponential learning/experience function) taking values in the range 0.005 to 0.035 with a step of 0.005 . Simulation scenarios were accomplished for different initial sizes of brand product markets (300 to 900 units with step 100), for both stable and growing markets (7\% annually with step $2 \%$ ). The effect of each of the three potential strategic moves was tested by conducting the appropriate simulation experiments and by observing the behaviour of the output performance variables of Table I. 
Table I The system dynamics model's output variables

\begin{tabular}{lll}
\hline \multicolumn{1}{c}{ Variable Name } & \multicolumn{1}{c}{ Description } & Units \\
\hline 1. Total_Brand_Sales & Total units sold in forward supply chain & Product units \\
\hline 2. Total_Remanufactured_Quantity & Total units remanufactured by the retailer & Product units \\
\hline 3. OEM_Competitiveness & Retailer Unit REM price / OEM Unit price & Scalar \\
\hline 4. Retailer_Competitiveness & OEM Unit Price / Retailer Unit REM price & Scalar \\
\hline $\begin{array}{l}\text { 5. Remanufacturing_Capacity } \\
\text { 6. Remanufacturing_Capacity_Utilization }\end{array}$ & Retailer Remanufacturing Capacity & Product units/year \\
\hline $\begin{array}{l}\text { 7. Total_Production_Activity_ } \\
\text { Environmental_Impact }\end{array}$ & $\begin{array}{l}\text { The environmental effect of brand production, } \\
\text { recycling and remanufacturing. }\end{array}$ & $\begin{array}{l}\text { Average mass } \\
\text { equivalent of } \\
\text { production output in Kg }\end{array}$ \\
\hline $\begin{array}{l}\text { 8. Total_Material_Use } \\
\text { 9.Total_Material_Disposed }\end{array}$ & $\begin{array}{l}\text { Total quantity used in brand production, } \\
\text { recycling and remanufacturing }\end{array}$ & $\begin{array}{l}\text { Average product unit } \\
\text { equivalent mass in Kg }\end{array}$ \\
\hline $\begin{array}{l}\text { 10. Environmental_Impact_of_OEM_ } \\
\text { Logistics }\end{array}$ & $\begin{array}{l}\text { Used products, and disposed materials in brand } \\
\text { production, recycling and remanufacturing }\end{array}$ & $\begin{array}{l}\text { Average product unit } \\
\text { equivalent mass in Kg }\end{array}$ \\
\hline $\begin{array}{l}\text { 11. Environmental_Impact_of_Retailer_ } \\
\text { operations. }\end{array}$ & $\begin{array}{l}\text { Impact of retailer logistics of remanufacturing } \\
\text { operations. }\end{array}$ & $\begin{array}{l}\text { litres x km } \\
\text { litres x km }\end{array}$ \\
\hline
\end{tabular}

\subsection{The effect of order rationing}

In the base order rationing scenario, it was assumed that the OEM rations the retailer's orders for a period of six months, followed by a six month of normal order fulfilment. Rationing obviously, resulted in less brand products reaching end customers (sales). The results of the simulations indicated that OEM competitiveness decreased with rationing, because order backlogs built up, the production of brand new products was slowed down, and cumulative production learning effects were weaker. As a result, brand product prices remained slightly higher. The OEM was more competitive in stable markets than in expanding ones (Figure 2, left) where the effects of shortages were more visible. Expanding markets provided increasing streams of used products and a better business opportunity for the retailer/remanufacturer. It should be noted that competitiveness values in Figure 2 are averages for each 6-year simulation run. 


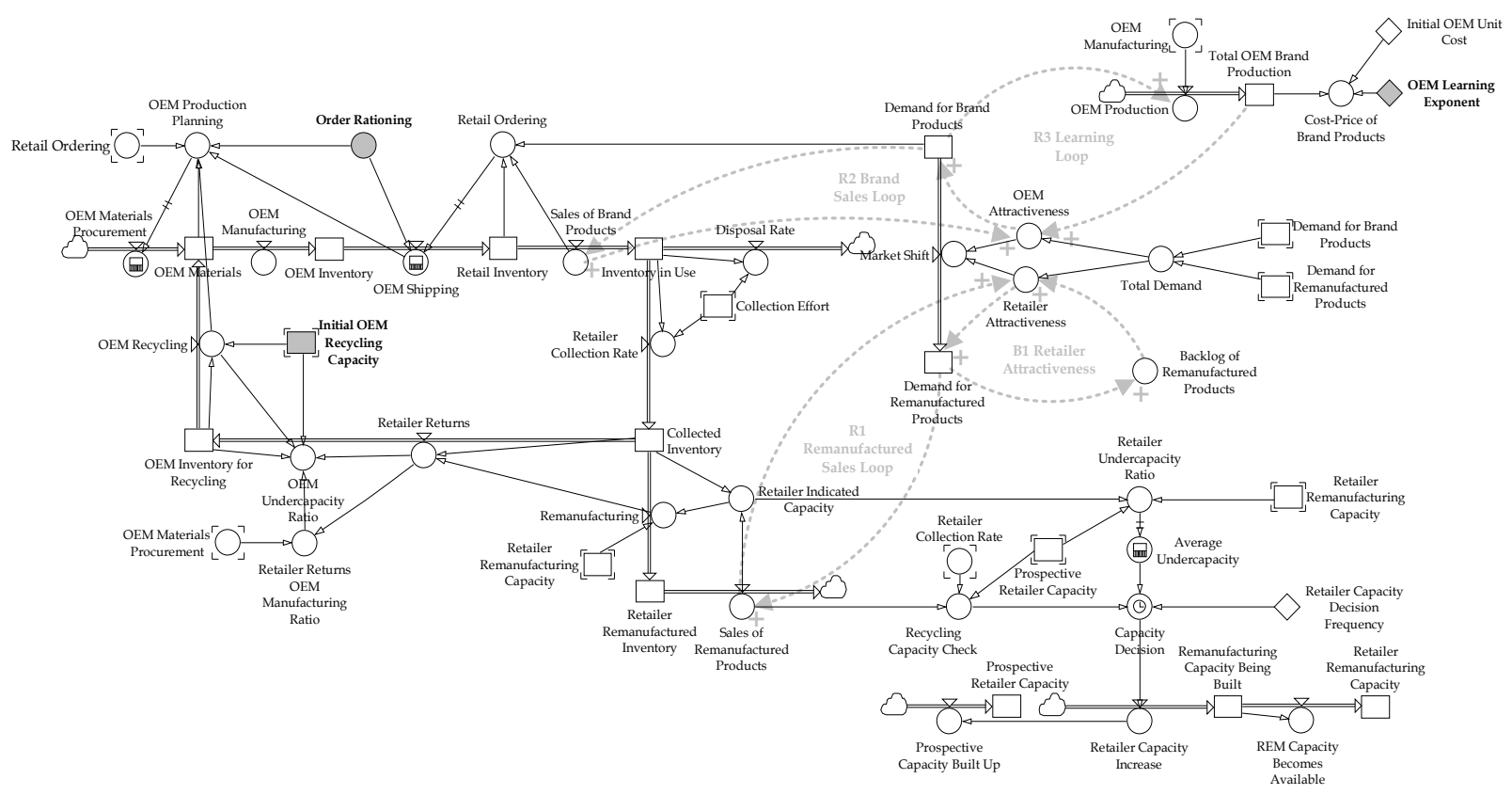

Figure 2 Core stock and flow structure of the supply chain model.

With no rationing, simulation results showed that the capacity utilisation of the retailer ranged from $70 \%$ for a large initial market (900 units per year), to $85 \%$ for a small one (300 units per year). This result was independent of the market growth rate. Rationing seemed to have some impact on the retailer's capacity utilisation only in small, stable and growing markets. Retailer's utilisation increased because the retailer built less capacity. Nevertheless, it was observed that, in some cases, rationing in small markets starved the brand market, and caused a delayed reduction in the collection and remanufacturing activities of the retailer.

Regarding the environmental effects of rationing strategies, a marginal improvement of the environmental performance of the entire supply chain was observed as the percentage of rationing increased and resulted in less production activity and less negative environmental impact (Figure 3). This improvement was more evident in large brand markets. However, the overall production activity that corresponded to the size of the market seemed to be a more influential factor for environmental performance than rationing, as it was directly connected to the manufacturing and remanufacturing activity, use of materials, and the quantities disposed. 

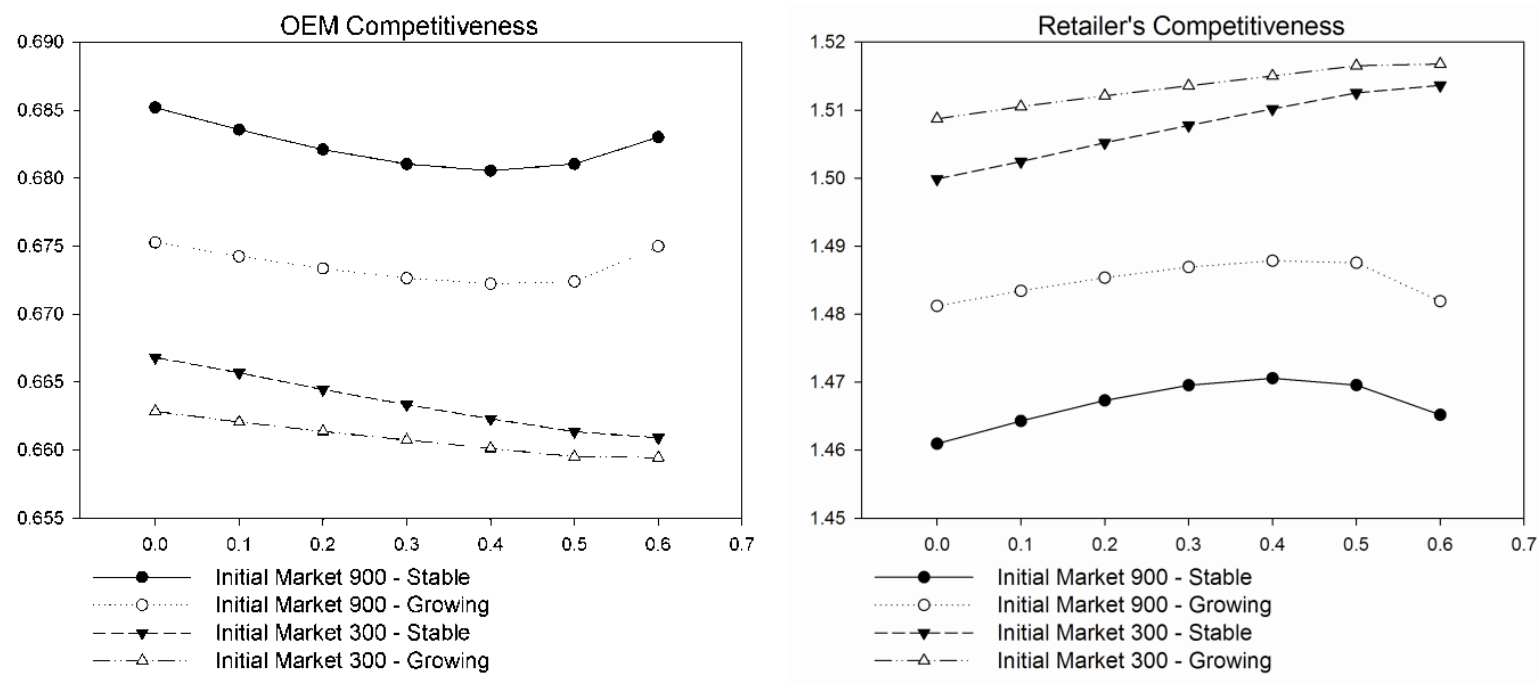

Figure 3 Effect of rationing on OEM (left) and retailer (right) competitiveness

\subsection{The effect of initial recycling capacity}

Simulations of the model revealed that increasing the OEM's initial (pre-emptive) recycling capacity increases, its competitiveness in large and small brand markets. The retailer's competitiveness exhibited the opposite behaviour. This is so because an increase in recycled materials used, reduces the production cost of OEM new products and reduces the retailer's competitiveness. Figure 4 shows the average competitiveness in each 6-year simulation scenario for both competitors. In small markets, the availability of recycling capacity at early stages, allows greater quantities of used products to be recycled. This reduces the unit cost of the OEM and increases the attractiveness of brand new products. However, in every scenario the retailer gradually develops his remanufacturing capacity and uses more of the products it collects (instead of forwarding them to the OEM). The attractiveness of remanufactured products increases and a corresponding shift in demand takes place, thus there are less used products for collection. Both of these factors result in a reduction in the return flow to the OEM. The initial increase in OEM attractiveness due to the recycled materials in new product manufacturing is not sufficient to offset this development. Hence, OEM_Inventory_for_Recycling is reduced (Figure 5). Thus, early recycling capacity increases the OEM's competitiveness, in small markets. Overall, the reduction in OEM_Inventory_for_Recycling is not directly proportional to the initial value of recycling capacity because of the compensating effect of Retailer_Remanufacturing_Capacity. As the OEM recycles more, it becomes more competitive, and the retailer has reduced incentive to build remanufacturing capacity. Hence, more than expected products are sent for recycling increasing the corresponding inventory. 

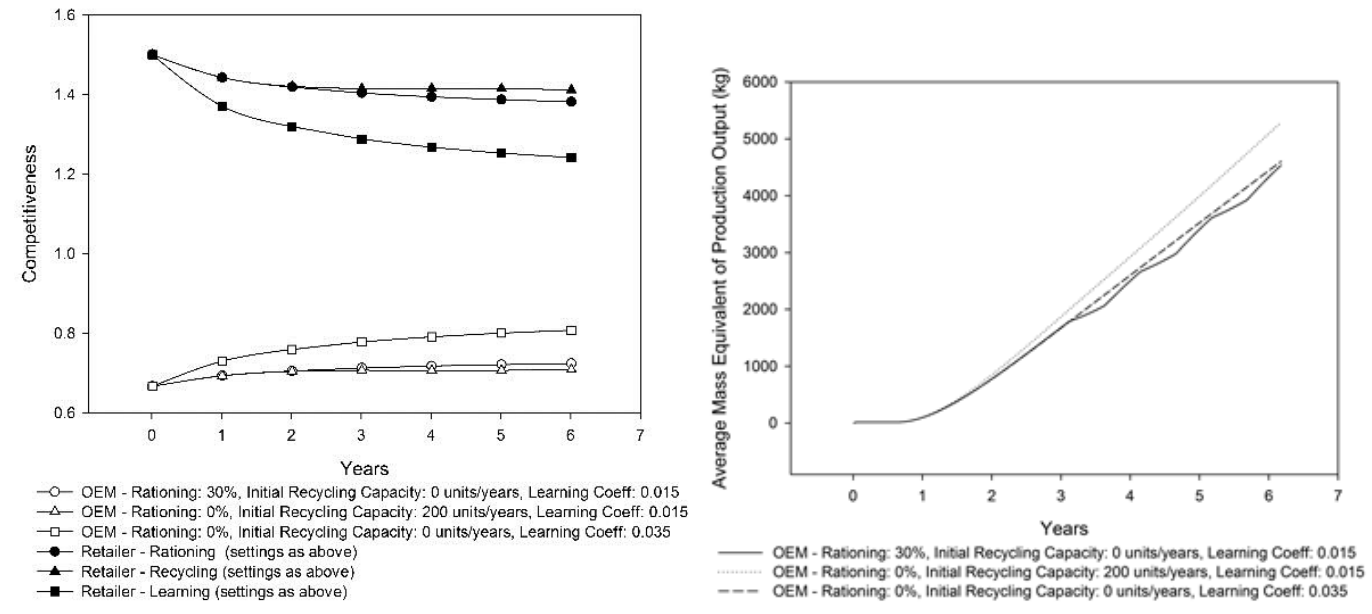

Figure 4 Average competitiveness for OEM and retailer.
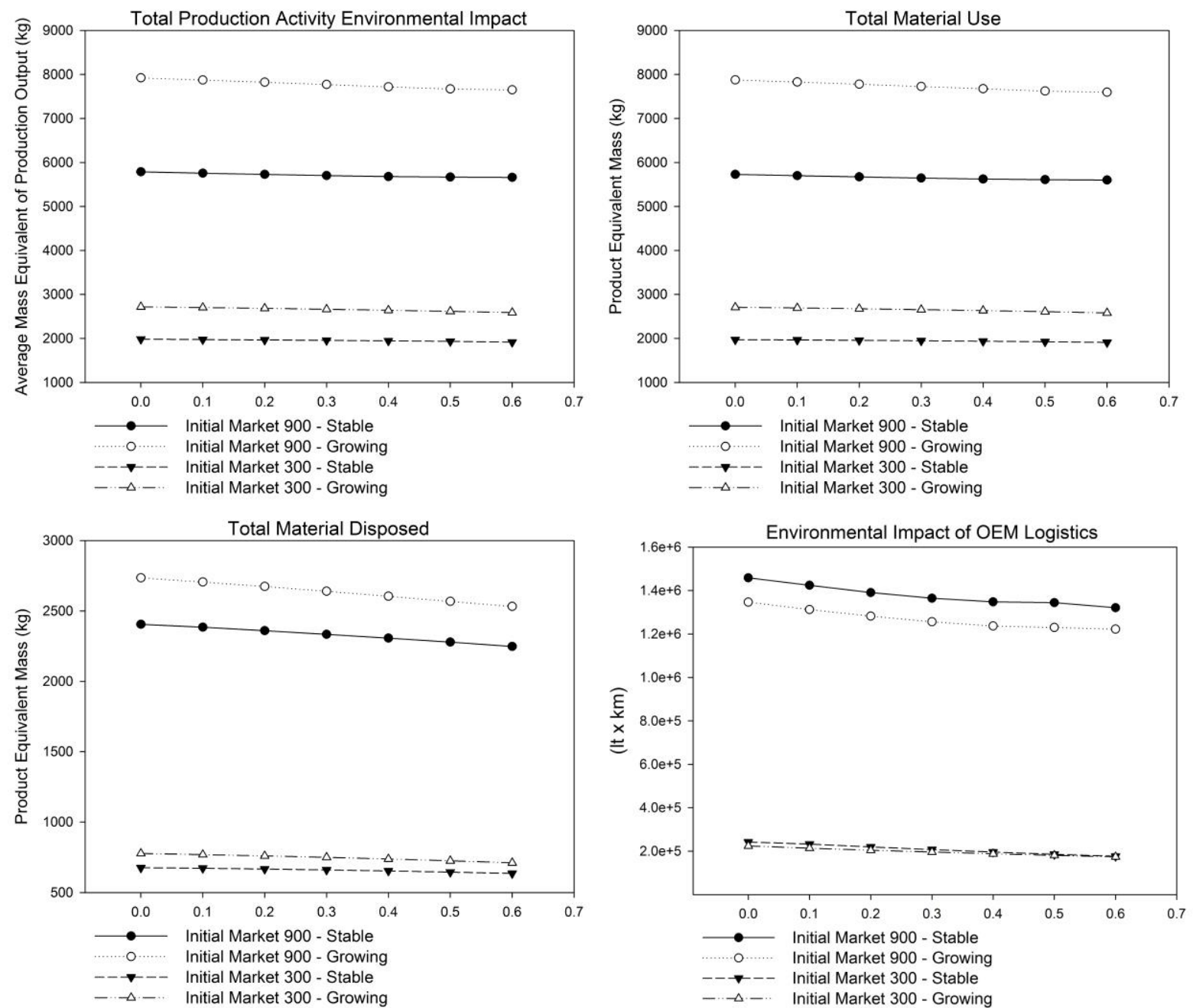

Figure 5 The effect of rationing on the environmental indicators of the supply chain indicated in each graph, for small and large initial markets, both stable and growing. 
The behaviour of environmental performance variables regarding pre-emptive recycling capacity strategy, is shown in Figure 6. Clearly, increasing the initial recycling capacity has the opposite effect to rationing. The OEM becomes more competitive in large markets, at the expense of the retailer, and consequently demand shifts to brand products. As a result the retailer struggles to develop capacity for remanufacturing, the remanufacturing loop weakens, and more used products were transported for recycling, thus worsening the environmental performance of the OEM's logistics (the burden was larger in large markets).
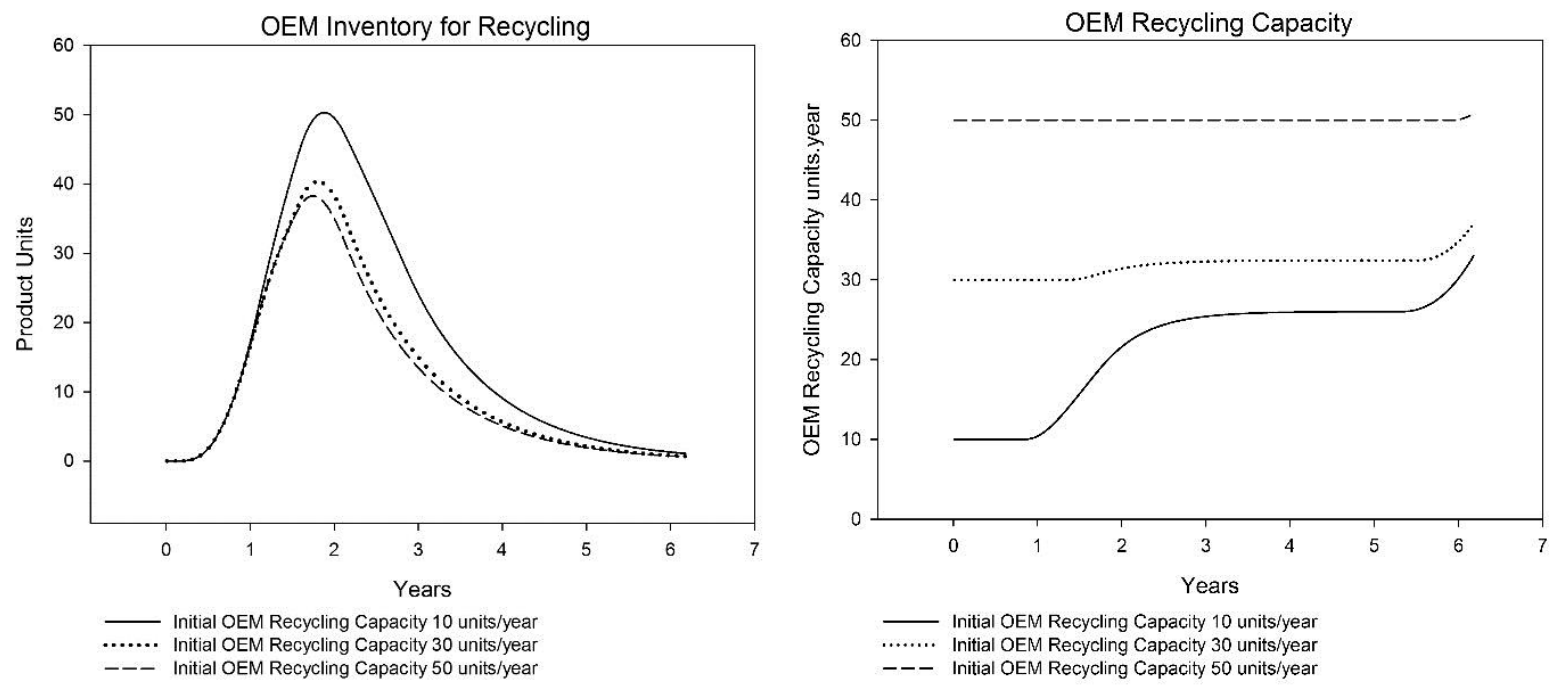

Figure 6 Temporal evolution of the OEM's recycling capacity and its inventory for recycling for different initial values of recycling capacity.

\subsection{The effect of OEM's pace of learning in production}

The simulation experiments conducted indicated that as the exponent of the production learning function was being increased, the competitive situation for the OEM improved at the expense of the retailer. However, the OEM could, at best, only approach the competitiveness of the retailer and it could not surpass it, because the gap in the initial competiveness due to the price differential could not be closed. The increase in the competiveness of the OEM had a minor effect on the retailer's capacity development and on the total number of remanufactured products. This result was independent of the market's size and its growth rate.

Finally, the pace of learning did not influence the environmental impact of production activity, the total material used, and the total material disposed, in both stable and growing markets, at any initial brand market size (learning is an "internal" variable not connected to any flow 
(decision/activity)). It only reduced the amount of components supplied to, and used by, the retailer thus reducing the environmental impact of its logistics operations.

\subsection{Sensitivity analysis}

A sensitivity analysis was conducted to assess the dependence of the model's variables (Table I) on the modelling assumptions and the associated parameter settings. The parameters chosen to vary for carrying out the analysis were:

1. The initial cost of remanufacturing (variation from 0.1 to 0.9 with step 0.1 monetary units).

2. The shipping delay in the forward and reverse link (variation from 1 to 4 weeks with step 1 week, for both).

3. The time lag between two successive rationing decisions (variation from 2 to 12 months with step 2 months).

4. The market shift delay - the speed at which customers switch between primary and secondary markets and vice-versa (variation from 2 to 6 months with step 2 months).

5. The contribution of recycling to OEM unit cost - percentage reduction in the cost of brand new products when produced from recycled materials (variation from $10 \%$ to $50 \%$ with step $10 \%)$.

6. The retailer's capacity building lead time - the time lag between the moment the decision to increase capacity is made, and the moment the capacity becomes available (variation from 6 to 18 months).

Every sensitivity-analysis parameter was tested with respect to the aforementioned three OEM strategy variables, i.e. initial recycling capacity building, rate of production learning, and percentage rationing on retailer's orders. The effect of varying each of the selected sensitivityanalysis parameters on all eleven output variables of Table I was observed after running appropriate simulations. Table II presents, in a compact qualitative form, the results obtained for the four sensitivity-analysis variables which had an impact on the most important (aggregate) output variables. 
Table II Results of sensitivity analysis on competitive and environmental variable

\begin{tabular}{|c|c|c|c|c|c|c|c|}
\hline $\begin{array}{l}\text { Sensitivity } \\
\text { variable }\end{array}$ & $\begin{array}{c}\text { OEM } \\
\text { Competitiveness }\end{array}$ & $\begin{array}{c}\text { Retailer } \\
\text { Competitiveness }\end{array}$ & $\begin{array}{l}\text { Total Production } \\
\text { Environmental } \\
\text { Impact }\end{array}$ & $\begin{array}{c}\text { Total } \\
\text { Materials } \\
\text { Use }\end{array}$ & $\begin{array}{l}\text { Disposed } \\
\text { Material }\end{array}$ & $\begin{array}{l}\text { Environmental } \\
\text { Impact of } \\
\text { Logistics OEM }\end{array}$ & $\begin{array}{l}\text { Environmental } \\
\text { Impact of } \\
\text { Logistics } \\
\text { Retailer }\end{array}$ \\
\hline $\begin{array}{l}\text { Market shift } \\
\text { time } \\
\text { (increase) }\end{array}$ & No effect - & No effect - & Increase $\uparrow$ & Increase $\uparrow$ & Increase $\uparrow$ & Decrease $\downarrow$ & Decrease $\downarrow$ \\
\hline $\begin{array}{c}\text { Recycling } \\
\text { contribution } \\
\text { to OEM unit } \\
\text { cost } \\
\text { (increase) }\end{array}$ & Increase $\uparrow$ & Decrease $\downarrow$ & No effect - & No effect - & $\begin{array}{c}\text { No effect } \\
-\end{array}$ & No effect & Decrease $\downarrow$ \\
\hline $\begin{array}{c}\text { Retailer } \\
\text { capacity } \\
\text { building time } \\
\text { (increase) }\end{array}$ & Increase $\uparrow$ & Decrease $\downarrow$ & Increase $\uparrow$ & Decrease $\downarrow$ & Increase $\uparrow$ & Increase $\uparrow$ & Increase $\uparrow$ \\
\hline $\begin{array}{c}\text { Initial } \\
\text { Retailer unit } \\
\text { cost } \\
\text { (increase) } \\
\end{array}$ & Increase $\uparrow$ & Decrease $\downarrow$ & Increase $\uparrow$ & Increase $\uparrow$ & Increase $\uparrow$ & Decrease $\downarrow$ & Decrease $\downarrow$ \\
\hline
\end{tabular}

The analysis indicated that the speed at which customers switch between the primary and secondary market, and vice-versa, has no impact on the competiveness of the two co-opetitors, but it increases the non-logistic environmental burden of the supply chain as more products are produced out of phase with the actual demand in each specific time period. Nevertheless, there is a decrease in the environmental effects of logistics, as fewer used products are transported to the OEM for recycling. On the other hand, as recycling materials contribute to the production of new products, increasing the contribution of recycling to the OEM's production activity increases its competitiveness (lower production cost).

Increasing the retailer's capacity-building lead time had a similar effect to OEM competiveness. Overall, the environmental performance of the supply chain deteriorated because the retailer was remanufacturing less. Only the amount of total materials used decreased because recycling increased. Finally, it was observed that increasing the initial retailer's unit cost, effectively, takes the retailer out of the reverse supply chain (less competitive and, consequently, reduced collection effort) and the environmental gains of remanufacturing are lost. There is only a reduction in the environmental effect of logistics because fewer products are being moved in the reverse supply chain. In summary, the results of sensitivity analysis emphasised, again, the contribution of the retailer's remanufacturing operations on the environmental performance of the entire supply chain. 


\section{Discussion}

This paper contributes to the debate on the compatibility of competitive and environmental strategies by extending existing research on competition in remanufacturing supply chains along three directions: First, it investigated the business and environmental effects of internal competition on a particular type of closed-loop supply chain, which had not been considered before, in which competition was between an OEM and its remanufacturing retailers for accommodating their products in the same market position. Second, by adopting the resourcebased perspective of competition, gaining competitive advantage was posed as a problem of managing levels of resource stocks by regulating flows. As the analysis required the use of research methods that could capture the dynamics of resource stock accumulation resulting from interacting management processes, the stream of strategic management research that uses dynamic models of resource-based competition was employed and a system dynamics model of the co-opetive situation under the resource-based perspective was developed. Third, in addition to measuring economic performance, environmental performance metrics were incorporated into the dynamic model to explicitly assess the effects of the operations strategies of the participants of the supply chain on the natural environment. The model was based on the structural characteristics of a co-opetitive situation in the industrial equipment sector, to which a resourcebased-theory-based operations-strategy-related decision structure was integrated.

In the case considered, the strategic decision space of the OEM was confined to operations strategy decisions concerning the development of pre-emptive capacity for increasing the efficiency of production, the adjustment of the intensity of production improvement efforts to lock up time compression diseconomies, as well as the more tactical decision of order rationing to take advantage of the dependence of retailer's resources. A large number of simulation experiments were conducted. The results indicated that order rationing does not increase the relative competitive position of the OEM in large markets, as much as it does in small ones. However, it improves the environmental performance of the entire supply chain as less material is being moved throughout the supply chain and as the retailers become more competitive absorbing more used products. This result was more evident in large and growing markets where the competitiveness of retailers was higher. Large initial (pre-emptive) recycling capacity, in large markets, improved the relative competitiveness of the OEM significantly, but it had a negative effect on the environmental impact of logistics. Otherwise, this strategy did not have any noticeable environmental effect. Faster learning and improvement of the production process 
seems to be a more effective strategy for increasing the competitiveness of the OEM, but its environmental contribution is limited. Experimentation with different initial conditions and/or different modelling assumptions confirmed the contribution of the retailer's operations to the improvement of the environmental performance of the entire supply chain.

In all the scenarios considered, independently of any mix of values of strategy variables, the competitiveness of the retailer/remanufacturer was higher than that of the OEM, although the OEM, in the course of time, could improve its performance by its strategic moves (especially by accelerating the pace of learning). Hence, the clear message of this explorative study is OEMs need to improve their competitiveness against third-party remanufacturers, especially when the latter own the non-operations-controlled strategic resource of customer relations, they are the sole collectors of used products, and can remanufacture with low costs. However, the OEMs have to balance the trade-off between increasing competitiveness on the one hand, and improving environmental performance on the other, which is the assumed incentive for remanufacturing. It should be noted that all the specific results obtained form the basis for new insights (propositions) whose extent of validity and strength, however, necessitates further empirical testing.

Overall, our study showed that increased OEM competitiveness, mirrored in low costs and prices, shrinks the market for remanufactured products, and retailers have no incentives to be involved in remanufacturing. In actual terms, as prices shrink and availability is not an issue, products become commodities and there is no economic value in remanufacturing. Obviously, recycling seems to be a better alternative. But recycling is also polluting, especially when performed in a small number of mega-sites, and bulky metallic products have to be transported by heavy vehicles over long distances. Therefore, in situations as the one considered in the paper, OEMs that want to be both competitive and environmentally benign, should be sceptical about remanufacturing and reconsider the relations and terms of competition with their retailers. They can either cooperate with them in remanufacturing, or organise an efficient recycling network that keeps recycling and use of acquired materials as close as possible to the point of their acquisition. Alternatively, they may follow a strategy, in which they are the sole collectors of used products and perform remanufacturing in a decentralised way. This is a pro-active strategy that requires tangible (capacity) and intangible (customer relations) resource commitments that will pay back gradually at later stages. Such a strategy keeps retailers in their usually assumed role, and their relationship to OEMs is not affected. Finally, a more radical strategy would be a change of the OEM's business model towards service provision (in contrast to product 
manufacturing and selling). In this, products/equipments are leased to the customers and a set of services, such as maintenance, upgrading, etc may be offered by the retailers/resellers.

\section{Conclusions}

Based on a case from the capital goods sector, and using system dynamics modelling, the research presented in this paper showed that efficient dynamic management of resources and tactical manoeuvres of Original Equipment Manufacturers, albeit increasing their environmental performance, are not sufficient to hinder remanufacturers from capturing the majority of the value present in end-of-life products if gate-keeping of the reverse logistics channel is left to them. In contrast, more cooperative and service-oriented strategies in both collection and reprocessing may increase the benefits of both competing parts, increasing, at the same time, the environmental performance of the entire supply chain.

\section{References}

Abdessalem, M., Hadj-Alouane, A.B., Riopel, D. (2012), "Decision modelling of reverse logistics systems: selection of recovery operations for end-of-life products", International Journal of Logistics Systems and Management, Vol. 13, No. 2, pp. 139-161.

Agrawal, V.V., Atasu, A. and van Ittersum, K. (2012), 'Remanufacturing, third-party competition, and consumers' perceived value of new products' Working Paper available at http://www.prism.gatech.edu/ aatasu3/index_files/AAV11.pdf (accessed 27/9/2012).

Akçal1, E. and Çetinkaya, S. (2011), 'Quantitative models for inventory and production planning in closed-loop supply chains', International Journal of Production Research, Vol. 49, No. 8, pp. 2373-2407.

Atasu, A., Guide, V.D. and Van Wassenhove, L.N. (2008), 'Product reuse economics in closedloop supply chain research', Production and Operations Management, Vol. 17, No. 5, pp. 483496.

Atasu, A., Guide, V.D. and Van Wassenhove, L.N. (2009), 'So what if remanufacturing cannibalizes new product sales?' California Management Review, Vol. 52, No. 2, pp. 56-76.

Blumberg, D.F. (2002), 'Strategic examination of reverse logistics and repair service requirements, needs, market size and opportunities', Journal of Business Logistics, Vol. 20, pp. 141-159.

Carter, C.R. and Ellram, L.M. (1998), 'Reverse logistics: a review of the literature and framework for future investigation', Journal of Business Logistics, Vol. 19, No. 1, pp. 85-102. 
Chen, J.M., Chang, C. (2012), 'The co-opetitive strategy of a closed-loop supply chain with remanufacturing', Transportation Research Part E: Logistics and Transportation Review, Vol. 48, No. 2, pp. 387-400.

Das, K. and Chowdhury, A.H. (2012), 'Designing a reverse logistics network for optimal collection, recovery and quality based product mix planning', International Journal of Production Economics, Vol. 135, No. 1, pp. 209-221.

Debo, L., Toktay, L.B., and Van Wassenhove, L.N. (2005), 'Market segmentation and production technology selection for remanufacturable products', Management Science, Vol. 51, No. 8, pp.1193-1205.

Debo, L.G., Toktay, L.B. and Van Wassenhove, L.N. (2006), 'Joint life-cycle dynamics of new and remanufactured products', Production and Operations Management, Vol. 15, No. 4, pp. 498-513.

Dierickx, I. and Cool, K. (1989), 'Asset stock accumulation and sustainability of competitive advantage', Management Science, Vol. 35, pp. 1504-1511.

Dowlatshahi, S. (2000), 'Developing a theory of reverse logistics', Interfaces, Vol. 30, No. 3, pp. 143-155.

El korchi, A. and Millet, D. (2011), 'Designing a sustainable reverse logistics channel: the 18 generic structures framework', Journal of Cleaner Production, Vol. 19, pp. 588-597.

Ferguson, M.E. and Toktay, L.B. (2006), 'The effect of competition on recovery strategies', Production and Operations Management, Vol. 15, No. 3, pp. 351-368.

Fleischmann, M., Bloemhof-Ruwaard, M.J., Dekker, R., van der Laan, E., van Nunen, A.E.E.J. and Van Wassenhove, L.N. (1997), 'Quantitative models for reverse logistics: a review', European Journal of Operational Research, Vol. 103, pp. 1-17.

Fleischmann, M., Krikke, H.R., Dekker, R. and Flapper, D.P. (2000), 'A characterization of logistics networks for product recovery', Omega, Vol. 28, pp. 653-666.

Fleischmann, M., Beullens, P., Bloemhof-Ruwaard, J.M., and van Wassenhove, L.N. (2001), 'The impact of product recovery on logistics network design', Production and Operations Management, Vol. 10, No. 2, pp. 156-73.

Gavronski, I., Klassen, R.D., Vachon, S. and do Nascimento, L.F.M. (2011), 'A resource-based view of green supply chain management', Transportation Research Part E, Vol. 47, pp. 872885 .

Gavronski, I., Klassen, R.D., Vachon, S., and do Nascimento, L.F.M. (2012), 'A learning and knowledge approach to sustainable operations', International Journal of Production Economics, Vol. 140, pp. 183-192.

Georgiadis, P. and Athanasiou, E. (2013), 'Flexible long-term capacity planning in closed loop supply chains with remanufacturing', European Journal of Operational Research, Vol. 225, No. 9, pp. 44-58. 
Gharbi, A., Pellerin, R. and Sadr, J. (2008), 'Production rate control for stochastic remanufacturing systems', International Journal of Production Economics, Vol. 112, pp. 37-47.

$\mathrm{Gu}$, Q.L. and Ji, J.H. (2008), 'An integrated logistics operational model of Remanufacturing/Manufacturing system based on the consumer market', International Journal of Logistic Systems and Management, Vol. 4, No. 1, pp. 21-39.

Guide, D., Jayaraman, V., Srivastava, R. and Benton, W.C. (2000), 'Supply chain management for recoverable manufacturing systems', Interfaces, Vol. 30, No. 3, pp. 125-142.

Hazen, B.T. (2011), "Strategic logistics disposition decisions: from theory to practice", International Journal of Logistics Systems and Management, Vol. 10, No. 3, pp. 275-292.

Heese, H.S., Cattani, K., Ferrer, G., Gilland, W. and Roth, A.V. (2005), 'Competitive advantage through take-back used products', European Journal of Operational Research, Vol. 164, pp. 143-157.

Hill, T. (2000), Manufacturing Strategy: Text and Cases, New York: Palgrave.

Jaber, M.Y. and El Saadany, A.M.A. (2009), 'The production, remanufacture and waste disposal model with lost sales', International Journal of Production Economics, Vol. 120, pp. 115-124.

Jayaraman, V., Patterson, R.A. and Rolland, E. (2003), 'The design of reverse distribution networks: models and solution procedures', European Journal of Operational Research, Vol. 150, No. 1, pp.128-149.

Kleber, R., Zanoni, S. and Zavanella, L. (2011), 'On how buyback and remanufacturing strategies affect the profitability of spare parts supply chains', International Journal of Production Economics, Vol. 133, pp. 135-142.

Kumar, S. and Putnam, V. (2008), 'Cradle to cradle: Reverse logistics strategies and opportunities across three industry sectors', International Journal of Production Economics, Vol. 115, pp. 305-315.

Kumar, V., Batista, L. and Maull, R. (2011), 'The impact of operations performance on customer loyalty', Service Science, Vol. 3, No. 2, pp. 158 - 171.

Kunc, M.H. and Morecroft, J.D.W. (2009), "Resource-based strategies and problem structuring: using resource maps to manage resource systems", Journal of the Operations Research Society, Vol. 60, pp. 191-199.

Larsen E. and Lomi, A. (2002), 'Representing change: a system model of organizational inertia and capabilities as dynamic accumulation processes', Simulation Modelling: Practice and Theory, Vol. 10, pp. 271-296.

Lewis, M., Brandon-Jones, A., Slack, N. and Howard, M. (2010), 'Competing through operations and supply: The role of classic and extended resource-based advantage', International Journal of Operations \& Production Management, Vol. 20, No. (10), pp. 1032-1058. 
Majumder, P. and Groenevelt, H. (2001), 'Competition in remanufacturing', Production and Operations Management, Vol. 10, No. 2, pp. 125-141.

Mitra, S. and Webster, S. (2008), 'Competition in remanufacturing and the effects of government subsidies', International Journal of Production Economics, Vol. 111, pp. 287-298.

Mollona, E. (2002), 'A competence view of firms and resource accumulation systems: A synthesis of resource-based and evolutionary models of strategy-making', In: Morecroft J., Sanchez, R., Heene, A. (Eds.), Systems Perspectives on Resources, Capabilities, and Management Processes, Elsevier Science, Oxford, pp. 93-125.

Mondal, S. and Mukherjee, K. (2006), 'Buy-back decision in managing reverse logistics', International Journal of Logistic Systems and Management, Vol. 2, No. 3, pp. 255-264.

Morecroft, J. (2007), Strategic Modelling and Business Dynamics: A Feedback Systems Approach, Chichester: John Wiley \& Sons.

Nalebuff, B.J., Brandenburger, A.M. (1996), Co-opetition, London: Harper Collins Business.

Östlin, J., Sundin, E. and Björkman, M. (2008), 'Importance of closed-loop supply chain relationships for product remanufacturing', International Journal of Production Economics, Vol. 115, No. 2, pp. 336-348.

Pettersson, A.I. and Segerstedt, A. (2012), 'Measurements of excellence in a supply chain', International Journal of Logistics Systems and Management, Vol. 13, No. 1, pp. 65-80.

Qiang, Q., Ke, K., Anderson, T. and Dong, J. (2013), 'The closed-loop supply chain network with competition, distribution channel investment and uncertainties', Omega, Vol. 41, pp. 186194.

Richey, R.G., Daugherty, P.J., Genchev, S.E. and Autry, C.W. (2004), 'Reverse logistics: the impact of timing and resources', Journal of Business Logistics, Vol. 24, No. 2, pp. 229-250.

Robotis, A., Bhattacharya, S. and Van Wassenhove, L.N. (2004), 'The effect of remanufacturing on procurement decisions for resellers in secondary markets'. European Journal of Operational Research, Vol. 163, pp. 688-705.

Sarkis, J., Zhu, Q. and Lai, K. (2011), 'An organizational theoretic review of green supply chain management literature', International Journal of Production Economics, Vol. 130, pp. 1-15.

Savaskan, C.R., Bhattacharya, S. and Van Wassenhove, L.N. (2004), 'Closed loop supply chain models with product remanufacturing', Management Science, Vol. 50, No. 2, pp. 239-252.

Seitz, M.A. (2007), 'A critical assessment of motives for product recovery: the case of engine remanufacturing', Journal of Cleaner Production, Vol. 15, pp. 1147-1157.

Setaputra, R. and Mukhopadhyay, S.K. (2010), 'A framework for research in reverse logistics', International Journal of Logistic Systems and Management, Vol. 7, No. 1, pp. 19-55. 
Seuring, S. and Müller, M. (2008), 'From literature review to a conceptual framework for sustainable supply chain management', Journal of Cleaner Production, Vol. 16, pp. 1699-1710.

Sheriff, K.M.M., Gunasekaran, A. and Nachiappan, S. (2012), "Reverse logistics network design: a review on strategic perspective", International Journal of Logistics Systems and Management, Vol. 12, No. 2, pp. 171-194.

Shulman, J.D., Coughlan, A.T. and Savaskan, R.C. (2011), 'Managing consumer returns in a competitive environment', Management Science, Vol. 57, No. 2, pp. 347-362.

Slack, N. and Lewis, M. (2008), Operations Strategy (2 ${ }^{\text {nd }}$ Edition), Harlow: Prentice Hall.

Spengler, T. and Schroter, M. (2003), 'Strategic management of spare parts in closed-loop supply chains: a system dynamics approach', Interfaces, Vol. 33, No. 6, pp. 7-17.

Srivastava, S.K. (2007), 'Green supply chain management: a state of the art literature review', International Journal of Management Reviews, Vol. 9, No. 1, pp. 53-80.

Sterman, J.D. (2000), Business Dynamics: Systems Thinking and Modeling for a Complex World. New York: McGraw Hill.

Tan, T., Güllu, R. and Erkip, N. (2009), "Using imperfect advance demand information in ordering and rationing decisions", International Journal of Production Economics, Vol. 121, pp. 665-677.

Thierry, M., Van Wassenhove, L.N., Van Nunen, J.A.E.E. and Salomon, M. (1995), 'Strategic issues in product recovery management', California Management Review, Vol. 37, No. 2, pp. 114-135.

Toffel, M.W. (2004), 'Strategic management of product recovery', California Management Review, Vol. 46, No. 2, pp. 120-141.

Vlachos, D., Georgiadis, P. and Iakovou, E. (2007), 'A system dynamics model for dynamic capacity planning of remanufacturing in closed-loop supply chains', Computers and Operations Research, Vol. 34, pp. 367-394.

Warren, K. (2008), Strategic Management Dynamics, Chichester: John Wiley \& Sons.

Xanthopoulos, A. and Iakovou, E. (2010), "A strategic methodological optimisation framework for the design of a reverse logistics network with forward supply channel synergies", International Journal of Logistics Systems and Management, Vol. 7, No. 2, pp. 165-183.

Zhou, Y., Xiong, Y., Li, G., Xiong, Z. and Beck, M. (2013), 'The bright side of manufacturingremanufacturing conflict in a decentralised closed-loop supply chain', International Journal of Production Research, Vol. 51, No. 9, pp. 2639-2651. 


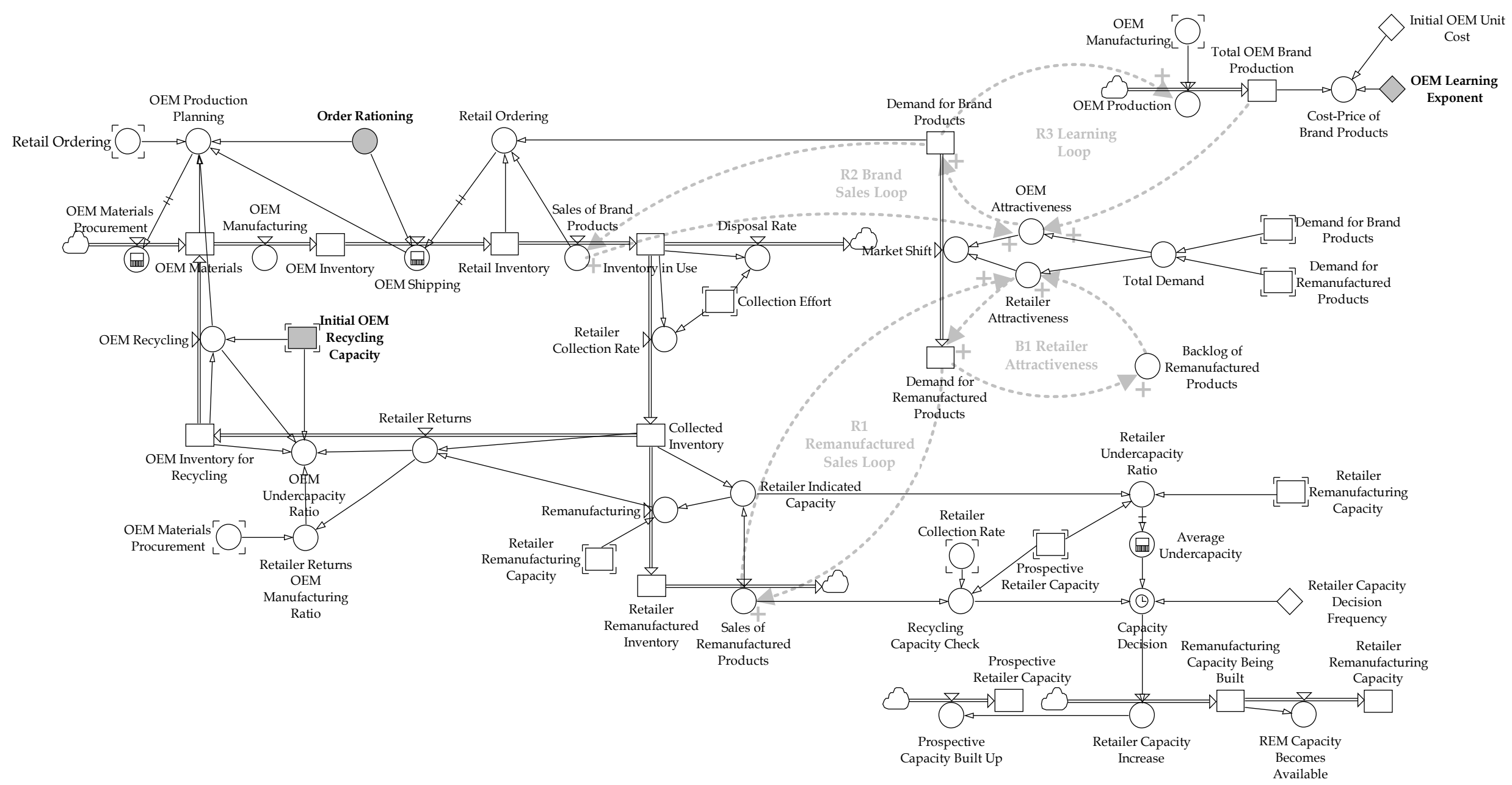

Figure 1. Stock and flow structure of the core of the supply chain model. 

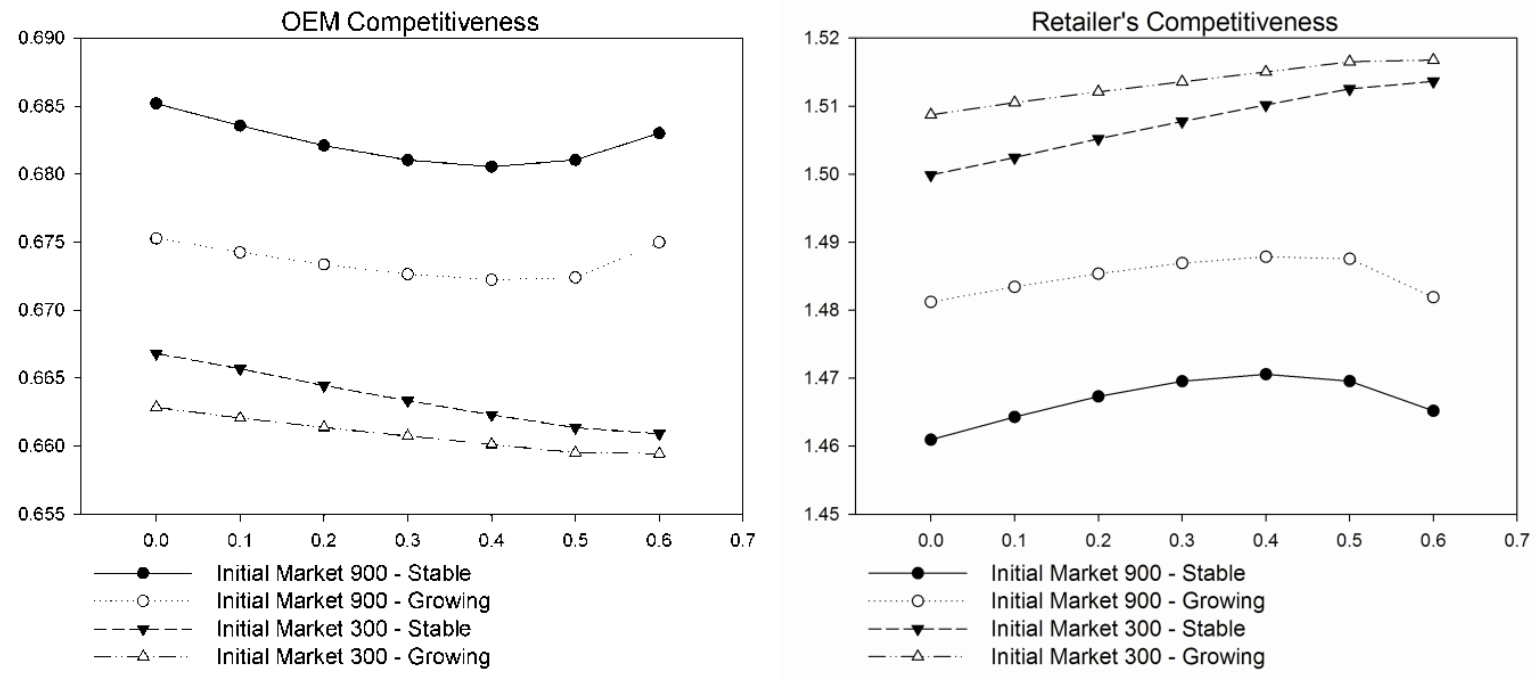

Figure 2. $\quad$ The effect of order rationing on the competitiveness of a) the OEM and $b$ ) the retailer/remanufacturer, in small and large initial markets, both stable and growing. 

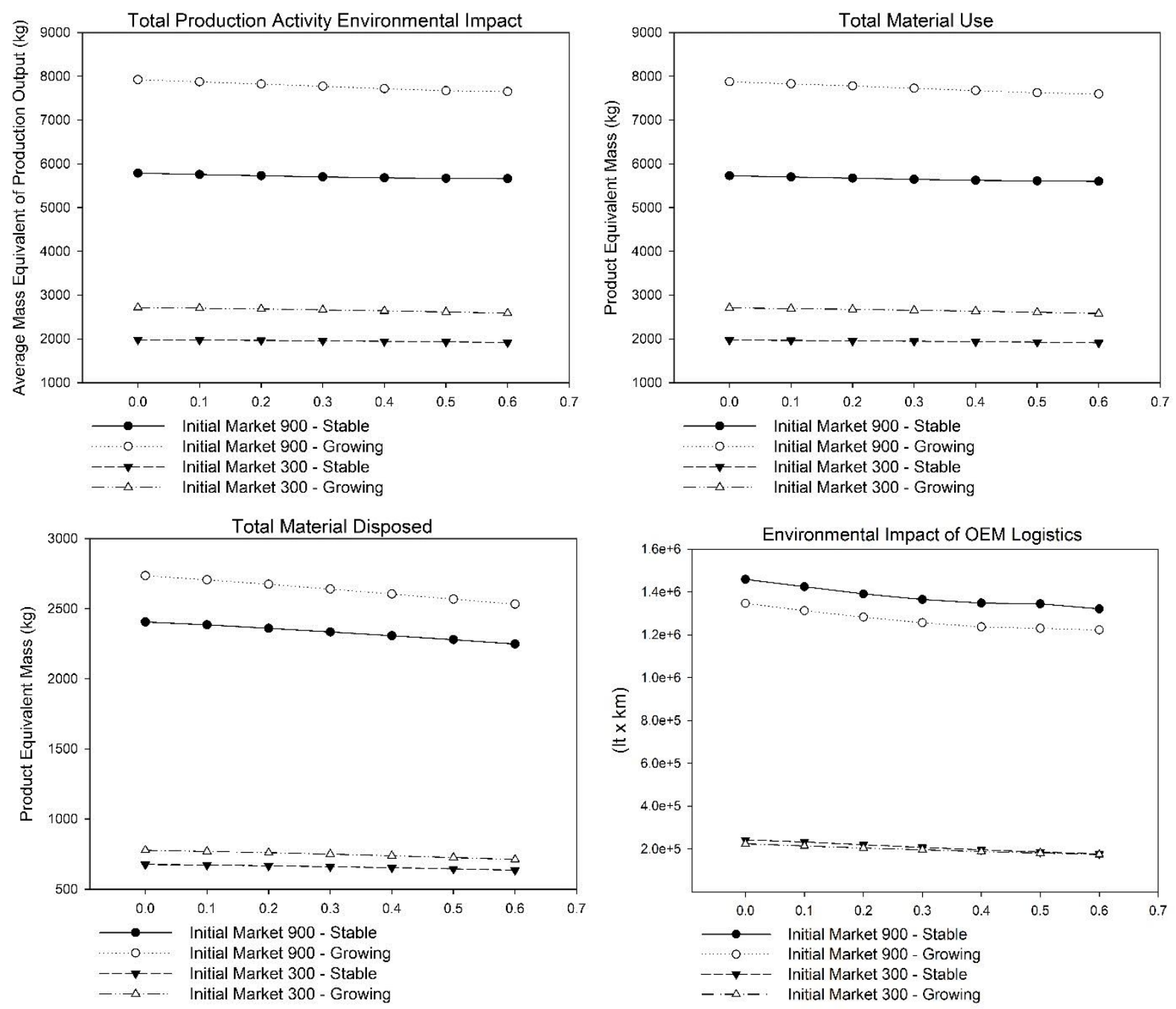

Figure 3. The effect of rationing on the environmental indicators of the supply chain indicated in each graph, for small and large initial markets, both stable and growing. 

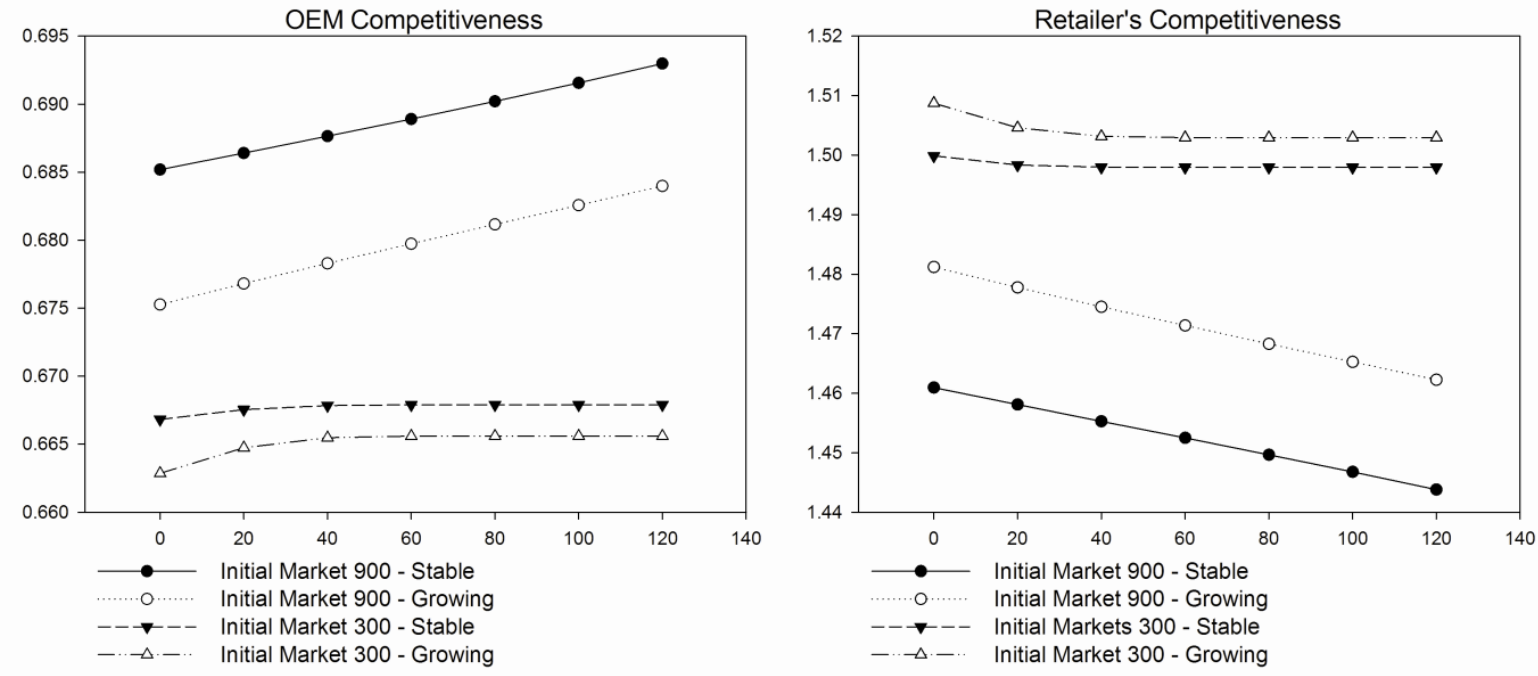

Figure 4. The effect of initial recycling capacity on the competitiveness of the OEM and the retailer/remanufacturer, for small and large markets, in stable and growing conditions. 


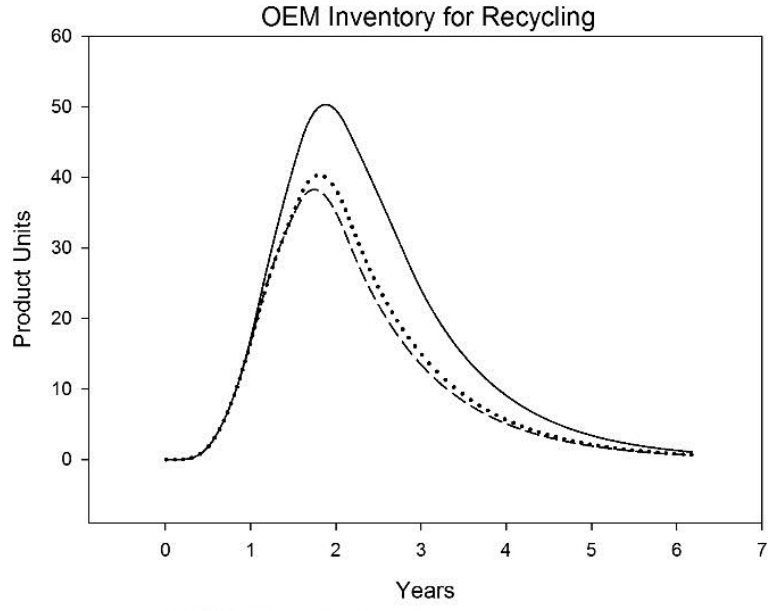

-...... Initial OEM Recycling Capacity 10 units/year -.... Initial OEM Recycling Capacity 30 units/year

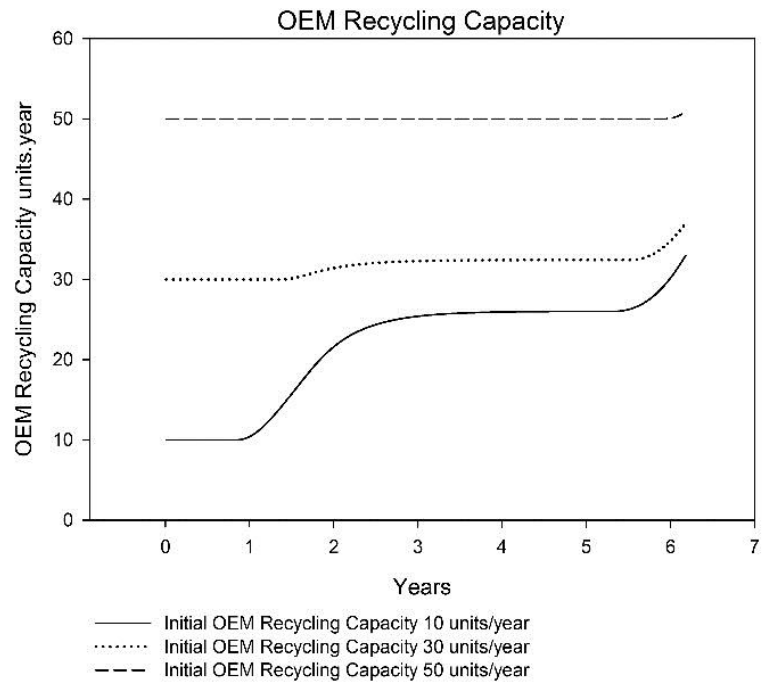

Figure 5. Temporal evolution of the OEM's recycling capacity and its inventory for recycling for different initial values of recycling capacity. 

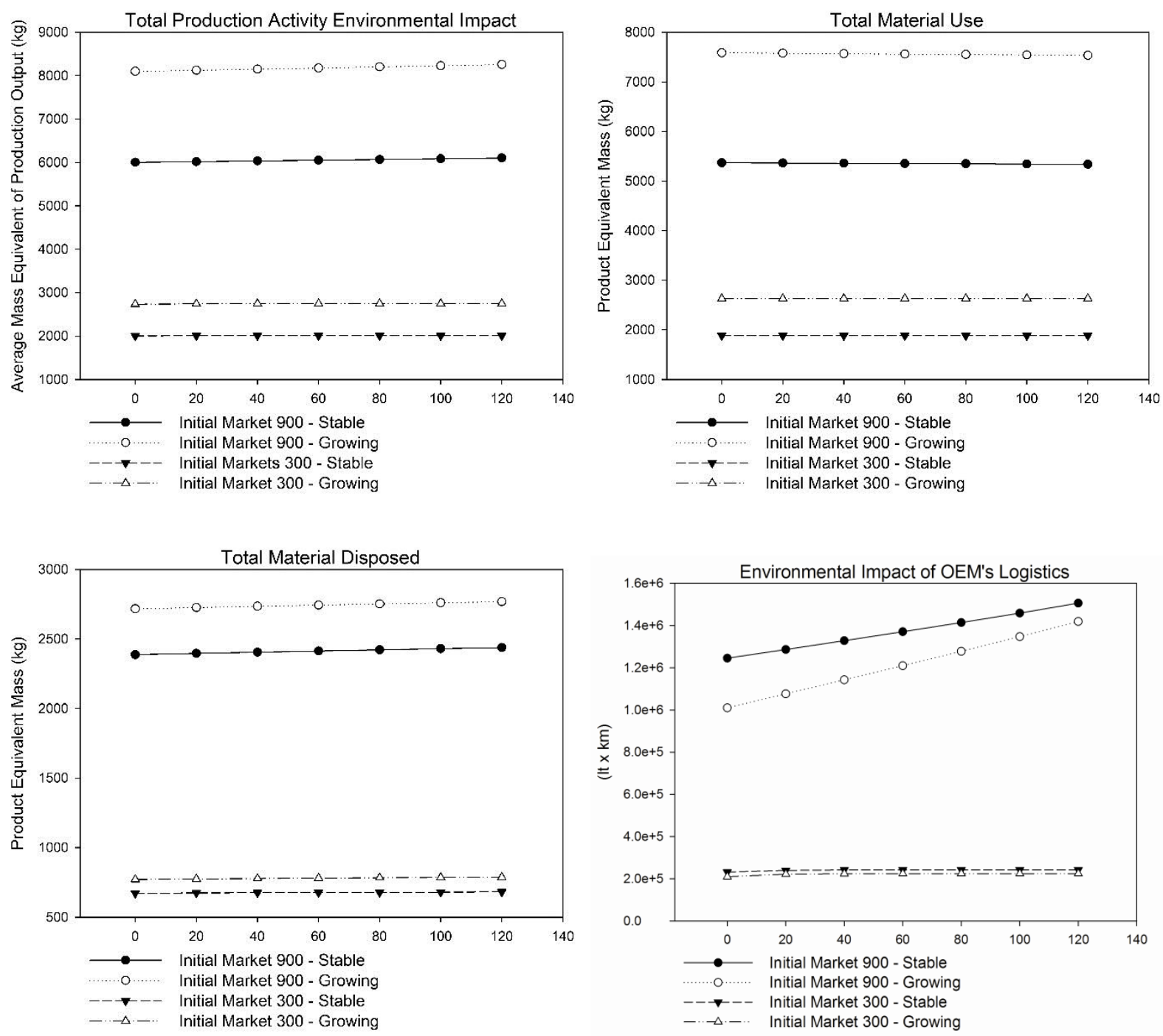

Figure 6. The effect of the OEM's production learning on the competitiveness of a) the OEM, and $b$ ) of the remanufacturer (small and large markets, stable and growing). 
Table I The system dynamics model's output variables

\begin{tabular}{|c|c|c|}
\hline Variable Name & Description & Units \\
\hline 1.Total_Brand_Sales & Total units sold in forward supply chain & Product units \\
\hline 2. Total_Remanufactured_Quantity & Total units remanufactured by the retailer & Product units \\
\hline 3. OEM_Competitiveness & Retailer Unit REM price / OEM Unit price & Scalar \\
\hline 4. Retailer_Competitiveness & OEM Unit Price / Retailer Unit REM price & Scalar \\
\hline 5. Remanufacturing_Capacity & Retailer Remanufacturing Capacity & Product units/year \\
\hline 6. Remanufacturing_Capacity_Utilization & Average Capacity Utilization & Percentage \\
\hline $\begin{array}{l}\text { 7. Total_Production_Activity_ } \\
\text { Environmental_Impact }\end{array}$ & $\begin{array}{l}\text { The environmental effect of brand } \\
\text { production, recycling and remanufacturing. }\end{array}$ & $\begin{array}{l}\text { Average mass } \\
\text { equivalent of } \\
\text { production output } \\
\text { in } \mathrm{Kg}\end{array}$ \\
\hline 8. Total_Material_Use & $\begin{array}{l}\text { Total quantity used in brand production, } \\
\text { recycling and remanufacturing }\end{array}$ & $\begin{array}{l}\text { Average product } \\
\text { unit equivalent } \\
\text { mass in } \mathrm{Kg}\end{array}$ \\
\hline 9.Total_Material_Disposed & $\begin{array}{l}\text { Used products, and disposed materials in } \\
\text { brand production, recycling and } \\
\text { remanufacturing }\end{array}$ & $\begin{array}{l}\text { Average product } \\
\text { unit equivalent } \\
\text { mass in } \mathrm{Kg}\end{array}$ \\
\hline $\begin{array}{l}\text { 10. Environmental_Impact_of_OEM_ } \\
\text { Logistics }\end{array}$ & $\begin{array}{l}\text { Impact of OEM logistics of recycling } \\
\text { operations. }\end{array}$ & litres $\mathrm{x} \mathrm{km}$ \\
\hline $\begin{array}{l}\text { 11. Environmental_Impact_of_Retailer_ } \\
\text { Logistics }\end{array}$ & $\begin{array}{l}\text { Impact of retailer logistics of } \\
\text { remanufacturing operations. }\end{array}$ & litres $\mathrm{x} \mathrm{km}$ \\
\hline
\end{tabular}


Table II Results of sensitivity analysis on competitive and environmental variables

\begin{tabular}{|c|c|c|c|c|c|c|c|}
\hline $\begin{array}{l}\text { Sensitivity } \\
\text { variable }\end{array}$ & $\begin{array}{c}\text { OEM } \\
\text { Competitiveness }\end{array}$ & $\begin{array}{c}\text { Retailer } \\
\text { Competitiveness }\end{array}$ & $\begin{array}{c}\text { Total } \\
\text { Production } \\
\text { Environmental } \\
\text { Impact }\end{array}$ & $\begin{array}{c}\text { Total } \\
\text { Materials } \\
\text { Use }\end{array}$ & $\begin{array}{l}\text { Disposed } \\
\text { Material }\end{array}$ & $\begin{array}{l}\text { Environmenta } \\
\text { I Impact of } \\
\text { Logistics } \\
\text { OEM }\end{array}$ & $\begin{array}{l}\text { Environmental } \\
\text { Impact of } \\
\text { Logistics } \\
\text { Retailer }\end{array}$ \\
\hline $\begin{array}{c}\text { Market shift } \\
\text { time } \\
\text { (increase) }\end{array}$ & No effect - & No effect - & Increase $\uparrow$ & Increase $\uparrow$ & Increase $\uparrow$ & Decrease $\downarrow$ & Decrease $\downarrow$ \\
\hline $\begin{array}{l}\text { Recycling } \\
\text { contribution } \\
\text { to OEM unit } \\
\text { cost } \\
\text { (increase) }\end{array}$ & Increase $\uparrow$ & Decrease $\downarrow$ & No effect - & No effect - & No effect - & No effect & Decrease $\downarrow$ \\
\hline $\begin{array}{c}\text { Retailer } \\
\text { capacity } \\
\text { building time } \\
\text { (increase) }\end{array}$ & Increase $\uparrow$ & Decrease $\downarrow$ & Increase $\uparrow$ & Decrease $\downarrow$ & Increase $\uparrow$ & Increase $\uparrow$ & Increase $\uparrow$ \\
\hline $\begin{array}{c}\text { Initial } \\
\text { Retailer unit } \\
\text { cost } \\
\text { (increase) }\end{array}$ & Increase $\uparrow$ & Decrease $\downarrow$ & Increase $\uparrow$ & Increase $\uparrow$ & Increase $\uparrow$ & Decrease $\downarrow$ & Decrease $\downarrow$ \\
\hline
\end{tabular}

